\title{
Determinants of non-conventional participation in Brazil
}

\author{
Guilherme Pires Arbache
}

\section{Abstract}

The present work aims to analyse participation in demonstrations, petitions and boycotts in Brazil. Using data from both World Values Survey and a Brazilian survey ran by the University of São Paulo, we perform logistic regressions to assess the impact of variables such as political efficacy, political trust and education on these different types of political participation. Following previous theoretical propositions and empirical evidences about the determinants of political participation, we found that education and political interest are powerful predictors of all types of action hereby studied in many of the models we tested. The size of the city presented some interesting results: in some models it is positively related with participation, and it is more significant for activities such as petitions where the relationship seem more intuitive, such as demonstrations, suggesting that bigger cities provide not only more opportunities for political action, but are also more susceptible to this type of action due to other factors, such as cultural variables that are not usually included in the political participation models.

Keywords: Political participation. Demonstrations. Petitions. Boycotts.

\section{Introduction}

Who participates in non-conventional forms of political action in Brazil? This article aims to investigate the determinants of participation in three types of political action: demonstrations, petitions and boycotts.

Non-institutionalized ${ }^{2}$ political participation has gained attention of political scientists lately, since they became more frequent than conventional

I Mestrando no Departamento de Ciência Politica da Universidade de São Paulo (DCP/USP). Email: guilherme. arbache@usp.br.

2 While the term "non-conventional" or "unconventional" participation is more frequent in the literature, authors such as Barnes, Kaase and Allerbeck (1979) prefer to talk about "non-institutionalized" participation. For Hooghe, Marien and Quintelier (2010), "non-conventional participation" is an inaccurate concept, given its chronological meaning, since activities such as petitions and boycotts already existed in 18th century). In turn. Conway (1990) defines unconventional participation as less socially accepted kinds of action. In the present work, we skip any divergence over the definition of such concepts, using non-institutionalized and non-conventional/unconventional participation interchangeably. 
types of action like party activism or even voting (NORRIS, 2002; DALTON, 2008; MARIEN; HOOGHE; QUINTELIER, 2010). Notwithstanding, there are still few studies on activities such as petitions and boycotts, especially when it comes to new democracies.

Most analyses on unconventional participationhave as their dependent variable eitherdemonstrationsorparticipationindexes whichput together many kinds of action ${ }^{3}$. The latter approach might have its benefits, since different types of non-conventional participation have many similarities that justify a combined analysis of them. However, each type of participationpresents its own levels ofcost and benefit (DALTON, 2008; COHEN; VALENCIA, 2008). The opportunities for participation available to each individual can also be different for each kind of political action. Therefore,

Additionally, studying non-institutionalized participation in countries with deep socioeconomic inequalities, such as Brazil, might helpto disclosuredifferent kinds of social cleavage, as compared to conventional participation (see MARIEN; HOOGHE; QUINTELIER, 2010). Moreover, new forms of governance that go beyond the state authorities have become more important in the last decades (HALE; HELD, 2011). Since nonconventional forms of participation constitute an important element of some of these new forms of governance (boycotts are strongly related to social and environmental labelling schemes, for example) studies on these types of political action (in a disaggregated fashion) seem relevant.

We choose protests, boycotts and petitions because these are the three most frequent kinds of non-conventional participation, suggesting some political relevance for them (and making statistical analysis more feasible). Moreover, we do not include illegal or violent participation because they are more susceptible to the "social desirability bias" (people tend to say they did not engaged in such types of action since they are less socially acceptable). Therefore, protests, petitions and boycotts are within an important threshold according to McAllister (1992), for whom boycotts stand exactly in the limit between legal activities (peaceful protests and petitions) and illegal ones

3 Kaase (1999), Norris (2002) and Dalton (2008) all employ "protest indexes" as dependent variables in their analyses. In Latin America, Booth and Seligson (2009) use a similar approach, as well as Ribeiro and Borba (2010)'s study on Brazilian participation. 
(occupying buildings, violent protests, street blocking, etc.). In turn, Cohen and Valencia (2008) propose a typology based on risks and costs of each kind of action. In this perspective, peaceful protest constitutes the most important threshold, since the costs and risks of boycotting and petitioning are very low (mainly because these activities do not involve face-to-face interaction), while illegal/violent action is much more risky and costly. Finally, previous research has shown that the patterns of participation in these peaceful types of action are very similar to the patterns of more conflictive ways of political action (DALTON, 2008).

Therefore, the present article presents an individual-level analysis of the determinants of protests, petitions and boycotts in Brazil, identify different patterns linked to the different costs with the following goals: an exploratory investigation about the many socioeconomic, demographic, political culture and psychological factors ${ }^{4}$ that could explain non-conventional participation, and tests of some well-known hypothesis of participation, to find out if they apply for the Brazilian case.

In the next sections, we briefly discuss some of the main theories on political participation and, more specifically, non-conventional participation. Then, we propose some explanatory variables and hypothesis. Finally, we proceed to a quantitative analysis of the determinants of protests, boycotts and petitions in Brazil, assessing the correlation of these types of action with education, income, political trust, political efficacy and some other variables that are considered important in the specialized literature.

\section{Theoretical background}

The scholar debate on political participation haslargely revolved around one of the most important theoretical frameworks in political science (and economics): the rational choice model. Departing from the pioneer work of Olson (1965) on collective action, followed by Downs (1957) and Riker and Ordeshook (1958) on electoral participation, further analyses aimed to solve the "paradox of participation": an individual would have no reason to pursue a public good (like the outcomes of participation) if he can enjoy this public

4 Contextual factors (such as economic growth and unemployment) and institutional factors (such as electoral systems) are not included since they are at the macro-level. 
good anyway. Therefore, scholars tried to overcome this puzzle by adding other factors to their explanatory models of political action, like psychological satisfaction or social rewards (LEIGHLEY, 1995). Olson, himself, had included "selective benefits" as an additional motivation to participate. Indeed, it is possible that someone engage in activities such as party activism with the intention to pursue a political career (see WHITELEY; SEYD, 1996).

We can summarize the explanations of political participation into three models: the rational choice, the "social psychological model", which places value on the role of psychological satisfaction and social norms, and the "resource model", based on the idea that people with more socioeconomic resources tend to participate more.

Whiteley and Seyd (1996) test the explanatory power of these three models and propose a "reduced model" which encompasses all of them. The results are more favourable to alternative approaches, while some rational choice variables even yielded some anomalous results: the coefficient for the cost of participation was in the opposite direction, suggesting that people who perceive higher costs tend to participate more in party activities.

Despite Whiteley and Seyd's empirical findings, it does not seem clever to ruleout, ex-ante, the rational choice from explanations. In terms of non-institutionalized participation, rational choice helps to explain some differences between the many types of action. Petitions are, by far, the most frequent form of political action among the three contained in this article (Figure 1), and it is also more frequent than most types of political action. That could be due to the lower costs of signing a petition, in comparison to other activities such as demonstrations (which demands a great amount of time) and boycotts (which might include financial costs). It seems more appropriate to include rational choice in a more comprehensive framework, as a complementary factor, instead of excluding it (Whiteley and Seyd do that in their own analysis). Individuals do take into accountindividual benefits and costs to participate, but that is not the only reason to participate or abstain from participating. However, individual-level studies, which, by definition, aim to inquiry on the reasons for individual differences on participation, do not profit from the rational-choice model by itself, since there seem to be little difference in costs and benefits (and the chance of being "pivotal" 
on guaranteeing such benefits) $)^{5}$, for a given kind of participation, among individuals. The resources model seem more useful for that matter, since people with higher socioeconomic status can afford the costs of participation easily than citizens from lower social classes.

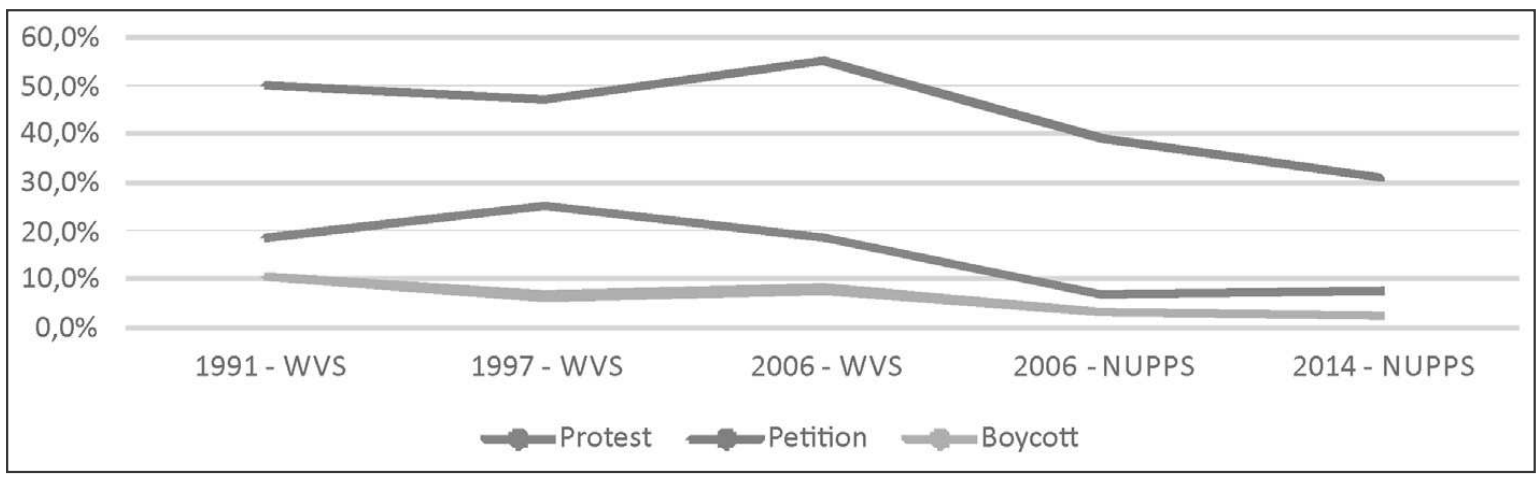

\section{Figure I - Rates of non-conventional participation in Brazil}

Sources: Wold Values Survey, NUPPS.

Supporting this comprehensiv eapproach, Brady, Schlozman and Verba (1995) propose that participation depends on ability, desire and opportunitiesto participate $^{6}$. The first dimension relates to the resources approach. The second one relates itself to political culture (in particular, political interest) and the expressive benefits proposed to solve the "participation paradox".

The opportunities dimension has not received attention on most scholarly work on participation yet. When it comes to electoral participation, this is not an issue, since the opportunities are straightforward: citizens either have or do not have the opportunity to vote. However, participation in protests, for example, is highly dependent on the exposure to opportunities of participation.

5 Simpler rational choice models rely on the idea of "pivotality" (i.e., the probability of someone casting the decisive vote in an election - which can be translated to other types of participation, e.g., being the person to sign a petition who made such petition effective for law proposals). Schwartz (1987) claimed that the probability of being decisive is so low in most cases that people do not actually think about that in order to vote. Nevertheless, even if we assume that pivotality is important for participation, it is obvious that every individual has the same probability of being "pivotal" or decisive in a given political action. Therefore, pivotality could only be relevant here if we controlled for differences in the belief of each individual on her chances of being pivotal.

6 It is worth to note that these authors, themselves, place little attention to the dimensions of "willingness" and "opportunities", focusing on resources: the only variables unrelated to skills and socioeconomic resources in their model are political interest and citizenship (since "it is a prerequisite for voting and might affect other kinds of participation as well"). 
There is little (if any) survey data available on opportunities to participate. Thus, direct control for opportunities is not always possible. Notwithstanding, it is possible (and necessary, in order to present a correct interpretation of findings) to understand individual differences on the opportunities of participation. Leighley (1995) claims that the correlation between socioeconomic variables and participation is misinterpreted by some scholars: socioeconomic status (SES) is related to social networks that bring more opportunities of participation. Hence, the effect of SES on participation happens also through opportunities. Besides that, interest in politics and associativism help creating more opportunities to participate (SCHUSSMAN; SOULE, 2005). Finally, one could expect town size to be positively correlated to participation since big cities provide more opportunities.

Some authors claimed that protest is a more adequate kind of action than voting for Olson's collective action approach, since this approach intended to explain high cost/high potential benefit activities (LEIGHLEY, 1995). Therefore, socio-psychological models gained special attention in studies of protest participation such as Muller and Opp (1986) and, more recently, Klandermans (2004). These studies focused on non-material benefits such as psychological satisfaction and personality. More recently, some authors assess the effect of the "Big Five" personality traits (Openness, Conscientiousness, Extraversion, Agreeableness, and Neuroticism) on protest participation alone (OPP; BRÄNDSTATTER, 2010) or together with other types of political action (MONDAK et al., 2010, 2011; GALLEGO; OBERSKI, 2012; WEINSCHENK, 2013). Nevertheless, many of such studies failed to find significant correlations between protest participation and personality traits.

Political culture (which we could arguably consider as part of the sociopsychological dimension, since it is mainly about motivations to participate) is also important. Explanatory variables such as political interest and political efficacy are among the most important predictors for participation. When it comes to unconventional participation, however, political trust arises as a main explanation. Indeed, many authors put aside the rational theory debate and started a dispute between the resources model and the disaffection model (DALTON, VAN SICKLE; WELDON, 2010). This debate overpassed the scholar realm andreached public opinion after the wave of protests that swept Brazil in 2013. In that occasion,both national and international observers 
started to wonder ifthe massive participation in the demonstrations was caused by political disaffection or, counter intuitively, by the improvement of socioeconomic conditions.

The latter explanation might seem a littleodd, since one would expect the improvement of citizen's lives to bring fewer reasons to reclaim things from State. Indeed, Dalton (2008) mentions the "deprivation approach", which claims that protest participationis a consequence of less socioeconomic resources, similarly to the disaffection approach. Nonetheless, many studiesshow that protest participation correlates positively with socioeconomic variables such as education, both in individual and macro levels. The events of 2013 in Brazil seem to fit well this trend: the rise of a middle class citizenry, who pays taxes and have new expectations toward life and toward the state, would be one of the reasons behind the wave of protests that spread across the country ${ }^{7}$.

On the other hand, the 2013 protests also seem to be a case of disaffection, since many protesters have clearly stated their dissatisfaction with those political institutions through slogans such as "sempartido" (without political parties). Therefore, these events might be an explosion of alatent distrust in political institutions which could be seen since the first opinion polls of the democratic regime, especially in institutions such as the Congresso Nacional (Chamber of Deputies) and the political parties (MOISÉS, 2005, 2010). In other countries, however, empirical studies reached discrepant conclusions on the correlation between political trust and non-institutionalized participation: while Kaase (1999) or Hooghe, Stolle and Micheletti (2005) found a negative and significant relationship, results were different in other analyses (NORRIS; WALGRAVE;VAN AELST, 2005; DALTON, 2008; DALTON; VAN SICKLE; WELDON, 2010).

Despite the opposition between the disaffection and resources approaches, the two explanations are not mutually exclusive. As Brady, Schlozman and Verba's theory proposes, one needs not only motivations (such as political disaffection) to participate, but also resources to do so. These two dimensions are complementary, as we insisted before.Indeed, individuals who engage on unconventional participationare more often than not "critical citizens":

7 For Singer (2013) the massive protests in Brazil were a mix of a "new proletariat" claiming for more economic gains with a traditional middle class politically discontent. 
individuals with high levels of education, political knowledge and expectancies toward the state. With high expectancies, come low levels of trust and satisfaction with political institutions (NORRIS, 1999; DALTON, 2004).

Therefore, we aim to assess the role of socioeconomic resources, political disaffection and political culture elements that raise willingness (like political interest and efficacy), as well as ideology (in terms of the right/left spectrum but also in terms of post-materialism/materialism, as explained below). We also include demographic variables that are often employed in participation studies, such asage and gender, as well as town size, which could be linked to opportunities of participation ${ }^{8}$. Other variables related to the social and political environment, such as social capital can also play an important role (since it raises the desire and the probability that opportunities to participate reach the individual through social networks of engaged citizens).

Still in the socio-psychological dimension (as Whiteley and Seyd call it), we have also included some psychological variables. Some studies above mentioned employ the "Big Five traits". However, these traits are not available at anyBrazilian surveys related to politics and participation. Therefore, we test for an influence of three variables related to Schwartz (1992) values typology: obedience, risk disposal and altruism.Ulbig e Funk (1999), on the other hand, point to a negative influence of conflict avoidance on political participation. Alesina e Giuliano (2011), in turn, find an indirect influence of the belief on the importance of obedience on participation. Civic duty was also pointed out as a relevant factor for participation (the variable for obedience employed here might be considered as a measure of concern with social norms than obedience, see Appendix). Finally, Fowler and Kam (2007) find experimental evidence that altruistic personalities (as well as group identification) are more prone to participate.

Thecausal mechanisms between these explanatory variables and political action is often very complex, even when they present a consensual correlation with participation throughout the literature, as it happens witheducation,

8 As stated before, we expect that large cities (in terms of population size) could have more opportunities of participation than small towns. Electoral participation studies often feature town size in their models (GEYS, 2006), though for a different reason: the probability of being pivotal is inversely correlated to the size of population. Therefore, they should predict negative coefficients, whereas we should predict positive coefficients for unconventional participation. 
political interest and efficacy.Socioeconomic resources, as previously mentioned, besides enabling citizens to engage(and to deal with the costs of participation), are also correlated withparticipation opportunities (LEIGHLEY, 1995). Political interest is not related exclusively to the desire, but it might also bring moreindividual opportunities to participate (SCHUSSMAN; SOULE, 2005). In addition, other factors, such as size of the town, can also correlate to social capital and opportunities for participation.In turn, age might have annulling effects (as one grows old, political interest increases, while physical willingness to participate decreases). Finally, there are spurious relationships, such as the mutual causality between perceptions of political efficacy and participation (FINKEL, 1985, 1987).

Rational choice is secondary here since, as previously mentioned, it does not account for direct individual differences on participation. Nevertheless, the rational calculus can have a role in the models hereby performed. The size of the town, for example, could affect not only opportunities of participation, but also the cost of each individual to participate (when we talk about protests). The same logic applies for socioeconomic variables. Living closer to a place where many demonstrations occur (such as Avenida Paulista, in Sáo Paulo which happens to be in one of the richer areas of this city), shapes not only opportunities of participation, but also the costs to do so. Lastly, having more economic resources makes participation costs more affordable too.

As mentioned above, we might expect different relationships between some explanatory variables and each kind of political action. Socioeconomic variables such as income do not have a significant relationship with many types of participation, even in works that emphasize the role of socioeconomic resources on participation, such as Brady, Schlozman and Verba (1995). In the present article, we suggest the hypothesis that boycottsare related to income while the other two types of participation hereby approached are not, since boycotting is directly related to money costs. On the other hand, one could expect political trust tobe linked to protest but not to other types of action (in particular, boycotting, since it is more often than not aimed at non-state actors such as companies).

In Figure 2, we propose a theoretical model of the causal links that lead to participation. An empirical model completely analogous to the framework proposed in this chart is not feasible due to the complexity of relationships 
just mentioned and limitations of data. Still, this chart seems useful to understand the main three dimensions of Brady, Schlozman and Verba (1995) that constitute participation (motivations, resources and opportunities).
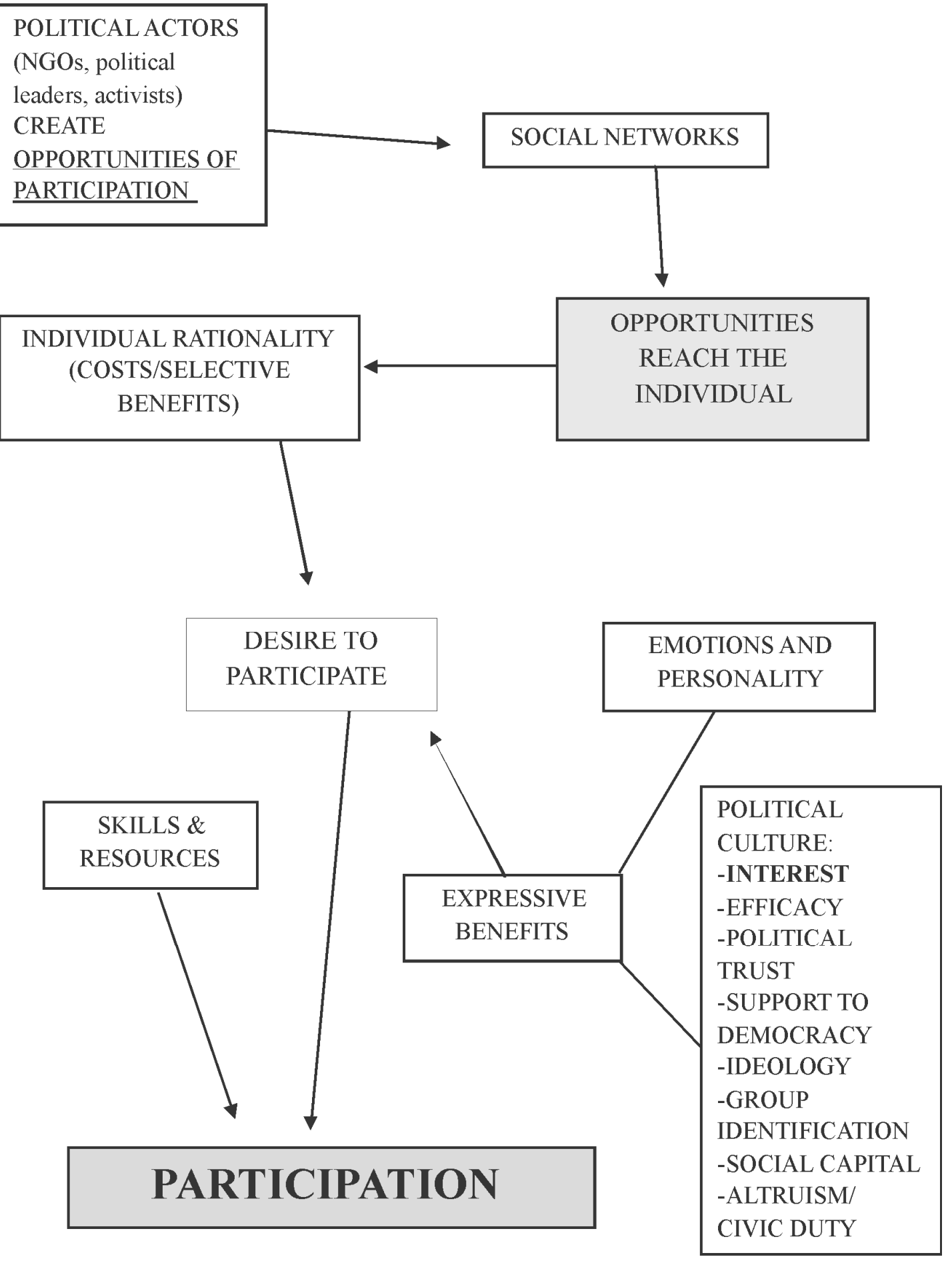

Figure $\mathbf{2}$ - Theoretical framework of the causes of participation 
Before proceeding to our analysis, we show an international comparison on the rates of participation in protests, petitions and boycotts. We can notice that Brazil is among the countries with highest rates of petition signing among the countries included in these figures (all the countries in World Values Survey wave of 2005 to 2007 that had data for recent participation). The rates of protest and boycott participation, on the other hand, place Brazil in a medium position.

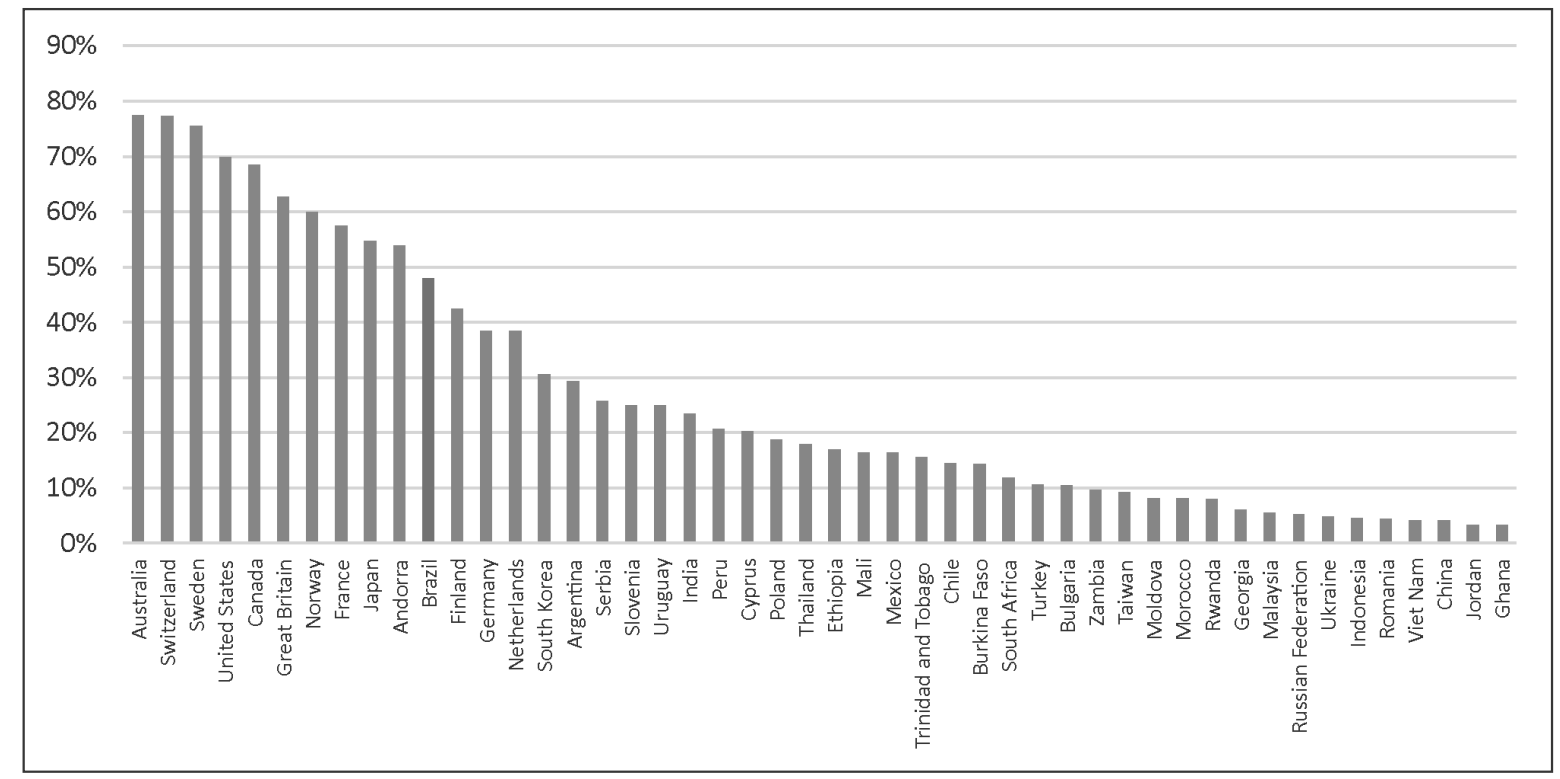

Figure $3-\%$ of interviewees that have recently signed petitions by country - WVS 2005-2007

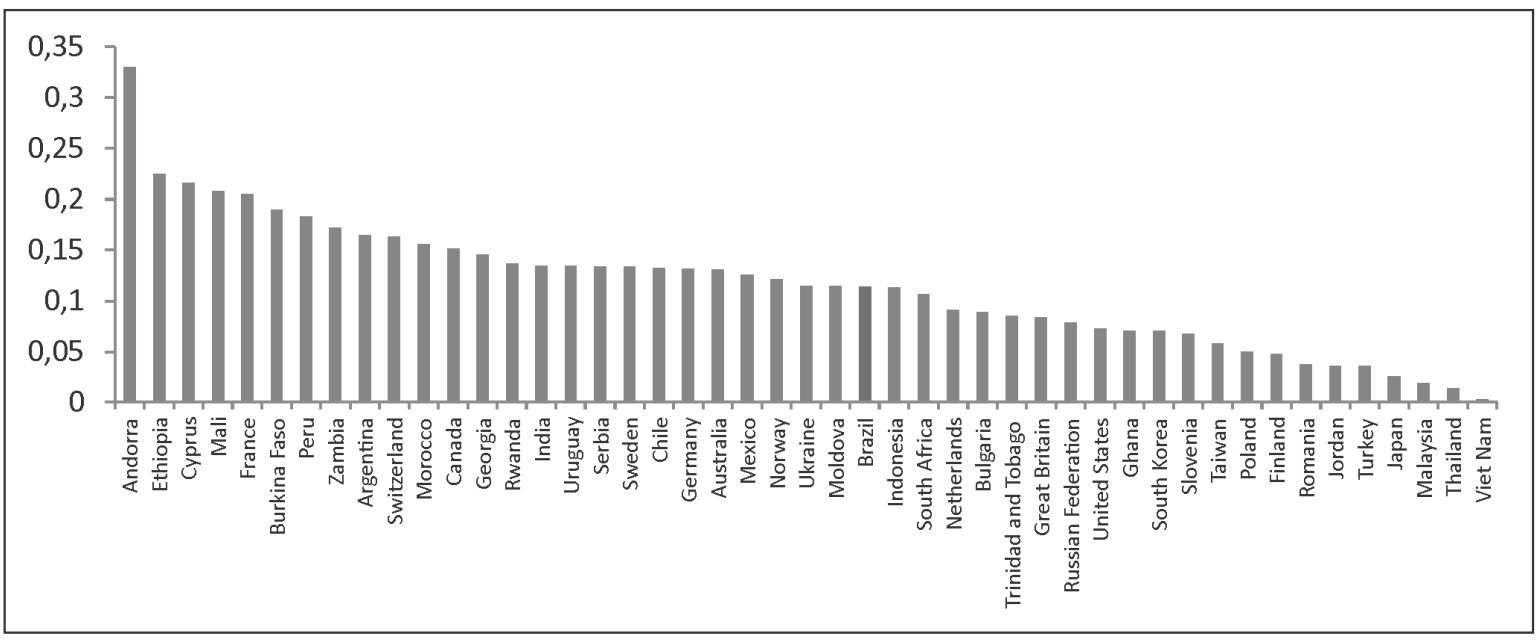

Figure $4-\%$ of interviewees that have participated recently in protests by country - WVS 2005-2007 


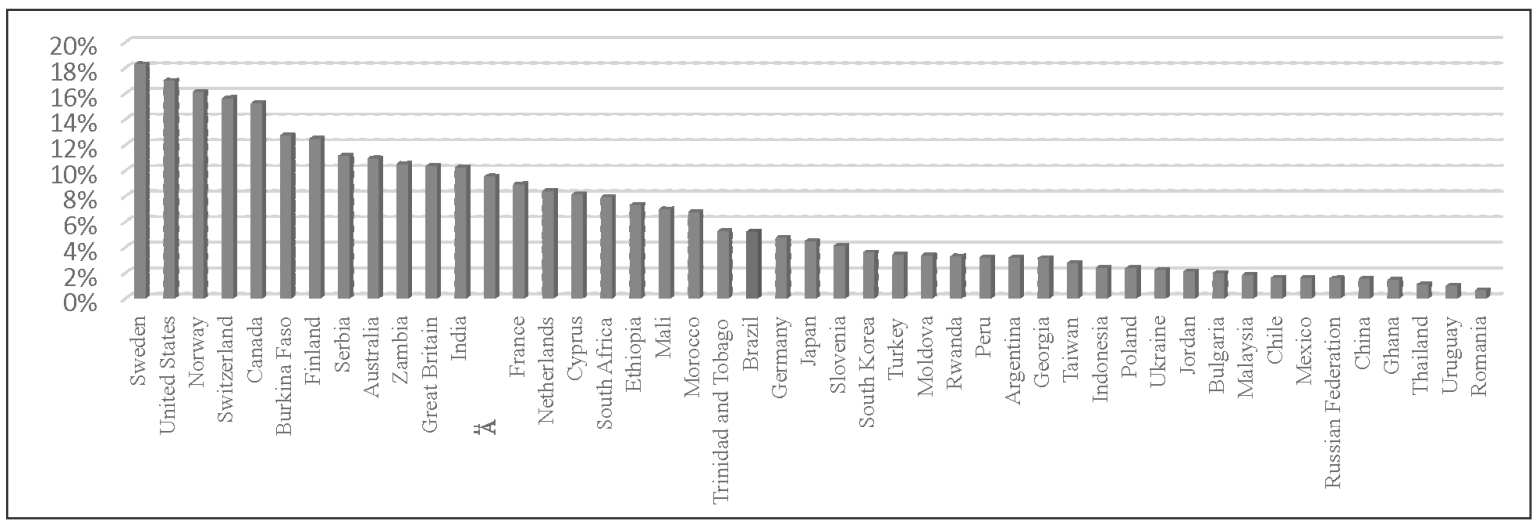

Figure 5 - \% of interviewees that have participated recently in boycotts by country - WVS 2005-2007

\section{Research design}

We perform logistic regressions ${ }^{9}$ with protests, boycotts and petitions as the dependent variables. The data sources are WVS (World Values Survey) as well as a public opinion survey conducted in 2006 by NUPPS (Research Centre for Public Policies Studies at Universidade de Sáo Paulo).

We make use of all WVS research waves carried out in Brazil: 1991, 1997 and 2006. With this data, we can have a broader comprehension of the trends in non-conventional participation during the democratic regime in the country, with three different time-points: one at the beginning of the democracy, another one a few years later, after the economic stabilization and the first elected government that finished its term, and a third one that is more recent, after some years of Worker's Party government. That might help avoiding distortions caused by contextual factors.

The NUPPS research has some useful variables, besides providing a different source of data, with a different sample, for 2006. That could help in our understanding of participation in contemporary Brazil and give as a clue about the underlying individual reasons for the 2013 protests.

9 All the analysis were performed on STATA software, version 12 (graphs were performed on $R$ and Microsoft Excel). Scripts are available upon request. 


\section{I Dependent variables}

Our dependent variables are all binaries, where $y=1$ means that the person "have participated" and 0 "have not participated".

- For both WVS and NUPPS models, $y=1$ means that the interviewee says he has participated in the respective form of political action at least one time in his life.

- We also have a model for WVS 2006 where the dependent variable measures recent participation. The difference between these two dependent variables has meaningful implications for our models. First, we expect different distributions since, for obvious reasons, the variablethat measures participation in the whole life has higher proportions of $y=1$. Secondly, these two variables might have different relationships with some independent variables, especially with age. The more one lives, more likely that she engaged at least once inher whole life in a given political activity (ceteris paribus, i.e., putting aside generational effects and other correlates of age). The probability of having recently participated on the same activity, on the other hand, might decrease with aging (especially if we consider physically demanding types of action like demonstrations).

\subsection{Independent Variables}

We included here all the independent variables that could be relevant, according to the theoretical proposals made above. In the APPENDIX A there is a detailed codebook of every dependent and independent variable featured in the analyses below. 
Table I - Independent variables and hypothesis related to them

\begin{tabular}{|c|c|c|}
\hline $\begin{array}{l}\text { Independent } \\
\text { variables }\end{array}$ & $\begin{array}{l}\text { Expected } \\
\text { correlation }\end{array}$ & Theoretical explanation \\
\hline \multicolumn{3}{|l|}{ socioeconomic: } \\
\hline Education & POSITIVE FOR ALL & $\begin{array}{l}\text { Participation requires information; education } \\
\text { is also related to social networks that bring } \\
\text { opportunities of participation }\end{array}$ \\
\hline Income & $\begin{array}{l}\text { POSITIVE FOR } \\
\text { BOYCOTTS }\end{array}$ & $\begin{array}{l}\text { Also related to social networks but it does not } \\
\text { seem sufficient for a significant relationship } \\
\text { according to previous studies. However, } \\
\text { boycotting often requires more money to pay for } \\
\text { more expensive items. }\end{array}$ \\
\hline Ocupation & $\begin{array}{l}\text { POSITIVE or } \\
\text { NEGATIVE }\end{array}$ & $\begin{array}{l}\text { Lesstime available decreases participation; but } \\
\text { more social connections increases participation. }\end{array}$ \\
\hline \multicolumn{3}{|l|}{ Demographic: } \\
\hline Age & $\begin{array}{l}\text { NEGATIVE (recent; } \\
\text { especially for } \\
\text { protests); POSITIVE } \\
\text { (all life) }\end{array}$ & $\begin{array}{l}\text { Younger people seem to participate more of } \\
\text { activities such as protests since they have } \\
\text { more physical disposition to act and a more } \\
\text { confrontational culture. The relation with life- } \\
\text { time participation was already explained. }\end{array}$ \\
\hline Gender (female) & POSITIVE & Women boycott more? \\
\hline Size of the city & $\begin{array}{l}\text { POSITIVE (especially } \\
\text { for protests) }\end{array}$ & $\begin{array}{l}\text { Bigger cities are more akin to a confrontational } \\
\text { culture (although that might be already } \\
\text { controlled by ideological variables) and they } \\
\text { are expected to have more opportunities of } \\
\text { participation in public demonstrations. }\end{array}$ \\
\hline \multicolumn{3}{|l|}{ Political culture: } \\
\hline Political interest & POSITIVE FOR ALL & $\begin{array}{l}\text { Interest is a requisite for participation, for obvious } \\
\text { reasons. Nevertheless, boycotting might be not } \\
\text { related to interest in politics (depending on what } \\
\text { the interviewees consider as "politics"), and } \\
\text { non-conventional participation might be related } \\
\text { to self-oriented goals and political alienation. }\end{array}$ \\
\hline Political trust & NEGATIVE FOR ALL & $\begin{array}{l}\text { A lack of trust in political institutions would } \\
\text { make citizens engage in acts isolated or even } \\
\text { against those institutions. }\end{array}$ \\
\hline
\end{tabular}




\begin{tabular}{|c|c|c|}
\hline $\begin{array}{l}\text { Independent } \\
\text { variables }\end{array}$ & $\begin{array}{l}\text { Expected } \\
\text { correlation }\end{array}$ & Theoretical explanation \\
\hline $\begin{array}{l}\text { Internal efficacy } \\
\text { (self-reported } \\
\text { comprehension of } \\
\text { politics) }\end{array}$ & POSITIVE FOR ALL & $\begin{array}{l}\text { To engage in political activities, one should feel } \\
\text { able to understand political issues. Downs ( } 1957 \text { ) } \\
\text { states that people with no information about } \\
\text { politics prefer to leave it to the well-informed. }\end{array}$ \\
\hline External efficacy & POSITIVE FOR ALL & $\begin{array}{l}\text { There is no point in participating if one does not } \\
\text { believe that his acts would make difference. }\end{array}$ \\
\hline $\begin{array}{l}\text { Attitude towards } \\
\text { democracy }\end{array}$ & POSITIVE FOR ALL & $\begin{array}{l}\text { Democratic attitude is a motivation to participate } \\
\text { (although non-conventional participation might } \\
\text { be related to disaffection for the regime) }\end{array}$ \\
\hline $\begin{array}{l}\text { Participation in civic } \\
\text { associations }\end{array}$ & POSITIVE FOR ALL & Also related to social capital \\
\hline \multicolumn{3}{|l|}{ Ideology: } \\
\hline Right-wing & NEGATIVE FOR ALL & $\begin{array}{l}\text { Leftists are believed to be more confrontational } \\
\text { (but that might depend on the orientation of the } \\
\text { government too) }\end{array}$ \\
\hline Post-materialist & POSITIVE FOR ALL & $\begin{array}{l}\text { Post materialists are believed to be more akin to } \\
\text { non-conventional participation }\end{array}$ \\
\hline \multicolumn{3}{|l|}{ Personality: } \\
\hline Risk-taker & $\begin{array}{l}\text { POSITIVE FOR } \\
\text { PROTESTS }\end{array}$ & $\begin{array}{l}\text { One needs to be more prone to risk-taking in } \\
\text { order to go protest. }\end{array}$ \\
\hline Obedient & $\begin{array}{l}\text { NEGATIVE FOR } \\
\text { PROTESTS (maybe } \\
\text { boycotts) }\end{array}$ & $\begin{array}{l}\text { People who value more obedience shall be less } \\
\text { prone to protesting. }\end{array}$ \\
\hline Altruism & POSITIVE FOR ALL & $\begin{array}{l}\text { Since one needs to go beyond self-interest to } \\
\text { participate, we expect a positive correlation here, } \\
\text { as found by (Fowler eKam, 2007). }\end{array}$ \\
\hline
\end{tabular}

\section{Analysis}

The following regression tables show that political interestis a powerful predictor for unconventional participation, yielding consistent results among the many different regression models tested ${ }^{10}$, with positive (and relatively big)

10 We have also carried out relogits and scobits, finding very similar results (all variables, in every model, had very similar coefficients and significance levels). We also tested bivariate regressions and multivariate models 
coefficients showing statistical significance for all models (even at the 0.001 level in almost all cases). There is no surprise on that. One needs to be interested in politics in order to participate. As we commented before, we might find no relationship or at least smaller coefficients for boycott participation, since it is not clear that the issues that people care when they boycott a product or brand are considered by the same individuals as "political". Nevertheless, the coefficients are in fact both substantively and statistically significant.

Education, in its turn, failed to show statistical significance when boycott was the dependent variable (Table 4). Only one model showed significance at the $5 \%$ level (p-value of 0.016 ), and another model has yielded a coefficient that would be significant only at higher levels (0.067).

The correlationwith protests and petition signing were both very consistent, with statistical significance even at the lowest levels for most of the analysis. This was highly expected, since education is one of the most powerful predictors of participation.

Size of the city also has shown some interesting results, with positive and significant coefficients for petitions in all but one model, while the other two types of participation yielded statistical significance only in a few models. Protests should have a stronger relationship with town size. Nevertheless, these results are inconclusive, especially if we consider the low variance in this independent variable (due to the little quantity of interviewees in smaller cities) which poses a technical problem for regression analysis.

In Table 2, income appears as negatively correlated with petition signing, with statistical significance at the 5\% level in the 2006 model for lifetime participation.

A positive attitude towards the democratic regime was positively correlated to petition signing in all models, and significant at the 5\% level in 2 of the 3 models where that variable was available. Political trust yielded a negative correlation, but it show statistical significance only for one of the models.

Income has shown statistical significance in two models of petition, but with opposite coefficients. The coefficient was very low in one of those models.

with less independent variables, since a high number of independent variables that have no real relationship with the dependent variable can distort some results. The results, once again, were very similar. The tables for these regression models are not shown here to save space, but they are available upon request to the author. 
Therefore, these results might be due to chance, and there is no clear evidence of the relationship between income and petition signing here.

Table 2 - Participation in petition signing - WVS

\begin{tabular}{|c|c|c|c|c|}
\hline & $\begin{array}{l}\text { (2006 - } \\
\text { Recent) }\end{array}$ & $\begin{array}{l}\text { (2006 - } \\
\text { Lifetime) }\end{array}$ & $\begin{array}{l}\text { (1997 - } \\
\text { Lifetime) }\end{array}$ & $\begin{array}{c}\text { (1991- } \\
\text { Lifetime) }\end{array}$ \\
\hline Main & $-0.0138^{* *}$ & -0.00589 & -0.00447 & -0.000116 \\
\hline Age & $(0.002)$ & $(0.181)$ & $(0.441)$ & $(0.982)$ \\
\hline Gender (female) & $\begin{array}{l}-0.123 \\
(0.364)\end{array}$ & $\begin{array}{l}-0.154 \\
(0.267)\end{array}$ & $\begin{array}{c}-0.00354 \\
(0.981)\end{array}$ & $\begin{array}{l}-0.283^{*} \\
(0.020)\end{array}$ \\
\hline Town size & $\begin{array}{l}0.123^{* *} \\
(0.004)\end{array}$ & $\begin{array}{l}0.234^{* * *} \\
(0.000)\end{array}$ & $\begin{array}{l}-0.0372 \\
(0.199)\end{array}$ & $\begin{array}{l}0.155^{* * *} \\
(\mathbf{0 . 0 0 0 )}\end{array}$ \\
\hline Ocupation & $\begin{array}{c}0.203 \\
(0.129)\end{array}$ & $\begin{array}{c}0.251 \\
(0.064)\end{array}$ & $\begin{array}{l}0.0918 \\
(0.554)\end{array}$ & $\begin{array}{c}0.312^{*} \\
(0.014)\end{array}$ \\
\hline Income & $\begin{array}{c}-0.00775 \\
(0.808)\end{array}$ & $\begin{array}{c}-0.076 I^{*} \\
(0.019)\end{array}$ & $\begin{array}{l}0.0535 \\
(0.177)\end{array}$ & $\begin{array}{l}0.112^{* *} \\
(0.001)\end{array}$ \\
\hline Education & $\begin{array}{l}0.133^{* * *} \\
(0.000)\end{array}$ & $\begin{array}{l}0.164^{* \star *} \\
(0.000)\end{array}$ & $\begin{array}{l}0.193^{* * *} \\
(0.000)\end{array}$ & $\begin{array}{l}0.0876^{*} \\
(0.016)\end{array}$ \\
\hline Internet & $\begin{array}{c}0.283 \\
(0.099)\end{array}$ & $\begin{array}{c}0.369^{*} \\
(0.046)\end{array}$ & & \\
\hline Political Interest & $\begin{array}{l}0.245^{* * *} \\
(0.000)\end{array}$ & $\begin{array}{l}0.255^{* * *} \\
(0.000)\end{array}$ & $\begin{array}{l}0.443^{* * *} \\
(0.000)\end{array}$ & $\begin{array}{l}0.320^{* * *} \\
(0.000)\end{array}$ \\
\hline Political Trust & $\begin{array}{l}-0.0667 \\
(0.397)\end{array}$ & $\begin{array}{l}-0.153 \\
(0.057)\end{array}$ & $\begin{array}{l}-0.400^{* * *} \\
(0.000)\end{array}$ & $\begin{array}{l}-0.114 \\
(0.084)\end{array}$ \\
\hline
\end{tabular}




\begin{tabular}{|c|c|c|c|c|}
\hline & $\begin{array}{l}\text { (2006 - } \\
\text { Recent) }\end{array}$ & $\begin{array}{l}\text { (2006 - } \\
\text { Lifetime) }\end{array}$ & $\begin{array}{l}\text { (1997- } \\
\text { Lifetime) }\end{array}$ & $\begin{array}{c}\text { (1991- } \\
\text { Lifetime) }\end{array}$ \\
\hline Interpersonal & 0.237 & -0.0821 & 0.227 & -0.220 \\
\hline Trust & $(0.276)$ & $(0.7 \mid 7)$ & $(0.589)$ & $(0.354)$ \\
\hline \multirow{2}{*}{ Right-wing } & -0.0333 & -0.0213 & -0.0221 & -0.0189 \\
\hline & $(0.220)$ & $(0.443)$ & $(0.396)$ & $(0.394)$ \\
\hline \multirow{2}{*}{ Post-materialist } & 0.0349 & 0.112 & $0.24 I^{* * *}$ & $0.121^{*}$ \\
\hline & $(0.558)$ & $(0.065)$ & $(0.000)$ & $(0.025)$ \\
\hline Democratic & $0.0724^{*}$ & $0.0977^{* *}$ & 0.0413 & \\
\hline Attitude & $(0.022)$ & $(0.002)$ & $(0.607)$ & \\
\hline \multirow{2}{*}{ Altruism } & 0.0927 & $0.190^{*}$ & & \\
\hline & $(0.232)$ & $(0.015)$ & & \\
\hline \multirow{2}{*}{ Risk-taker } & 0.00973 & -0.00150 & & \\
\hline & $(0.830)$ & $(0.974)$ & & \\
\hline \multirow{2}{*}{ Obedient } & -0.0809 & -0.0439 & & \\
\hline & $(0.122)$ & $(0.422)$ & & \\
\hline N & 1172 & 1175 & 917 & 1342 \\
\hline
\end{tabular}

p-values in parentheses

${ }^{*} p<0.05,{ }^{* *} p<0.01,{ }^{* * *} p<0.001$ 
Table 3 - Protest participation - WVS

\begin{tabular}{|c|c|c|c|c|}
\hline & $\begin{array}{l}\text { (2006 - } \\
\text { Recent) }\end{array}$ & $\begin{array}{c}(2006 \text { - } \\
\text { Lifetime) }\end{array}$ & $\begin{array}{c}\text { (1997- } \\
\text { Lifetime) }\end{array}$ & $\begin{array}{c}\text { (1991- } \\
\text { Lifetime) }\end{array}$ \\
\hline \multicolumn{5}{|l|}{ Main } \\
\hline \multirow[t]{2}{*}{ Age } & -0.00787 & 0.00581 & 0.00884 & -0.00954 \\
\hline & $(0.259)$ & $(0.304)$ & $(0.186)$ & $(0.143)$ \\
\hline \multirow{2}{*}{ Gender (female) } & -0.0797 & 0.109 & 0.144 & 0.219 \\
\hline & $(0.705)$ & $(0.533)$ & $(0.396)$ & $(0.150)$ \\
\hline \multirow{2}{*}{ Town size } & -0.0386 & 0.0285 & $0.0956^{* *}$ & 0.0220 \\
\hline & $(0.57 \mathrm{I})$ & $(0.616)$ & $(0.003)$ & $(0.595)$ \\
\hline \multirow{2}{*}{ Ocupation } & -0.273 & 0.0179 & 0.248 & 0.143 \\
\hline & $(0.193)$ & $(0.918)$ & $(0.159)$ & $(0.378)$ \\
\hline \multirow{2}{*}{ Income } & -0.0154 & -0.0331 & 0.0500 & 0.0315 \\
\hline & $(0.764)$ & $(0.437)$ & $(0.233)$ & $(0.408)$ \\
\hline \multirow{2}{*}{ Education } & $0.106^{*}$ & $0.152^{* \star *}$ & $0.137^{* *}$ & $0.132^{* *}$ \\
\hline & $(0.036)$ & $(0.000)$ & $(0.002)$ & $(0.001)$ \\
\hline \multirow{2}{*}{ Internet } & 0.468 & $0.475^{*}$ & & \\
\hline & $(0.063)$ & $(0.022)$ & & \\
\hline \multirow{2}{*}{ Political Interest } & $0.470^{* * *}$ & $0.390^{* * *}$ & $0.448^{* * *}$ & $0.648^{* \star *}$ \\
\hline & $(0.000)$ & $(0.000)$ & $(0.000)$ & $(0.000)$ \\
\hline Political & 0.0291 & -0.0914 & -0.0295 & 0.0151 \\
\hline Trust & $(0.809)$ & $(0.364)$ & $(0.743)$ & $(0.860)$ \\
\hline Interpersonal & 0.472 & 0.482 & $1.433^{* * *}$ & -0.363 \\
\hline Trust & $(0.099)$ & $(0.055)$ & $(0.001)$ & $(0.252)$ \\
\hline
\end{tabular}




\begin{tabular}{|c|c|c|c|c|}
\hline & $\begin{array}{l}\text { (2006 - } \\
\text { Recent) }\end{array}$ & $\begin{array}{l}\text { (2006 - } \\
\text { Lifetime) }\end{array}$ & $\begin{array}{c}\text { (1997- } \\
\text { Lifetime) }\end{array}$ & $\begin{array}{c}\text { (1991- } \\
\text { Lifetime) }\end{array}$ \\
\hline Right-wing & $\begin{array}{l}0.0473 \\
(0.251)\end{array}$ & $\begin{array}{l}-0.0135 \\
(0.697)\end{array}$ & $\begin{array}{l}-0.117^{* * *} \\
(0.000)\end{array}$ & $\begin{array}{c}-0.11 \mathbf{I}^{* * *} \\
(0.000)\end{array}$ \\
\hline Post-materialist & 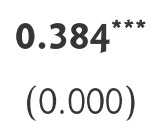 & 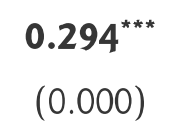 & 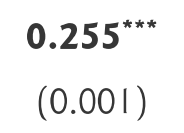 & $\begin{array}{l}\mathbf{0 . 1 7 0 * *} \\
(0.010)\end{array}$ \\
\hline $\begin{array}{l}\text { Democratic } \\
\text { Attitude }\end{array}$ & $\begin{array}{l}0.0866 \\
(0.145)\end{array}$ & $\begin{array}{c}0.110^{*} \\
(0.021)\end{array}$ & $\begin{array}{c}0.169 \\
(0.084)\end{array}$ & \\
\hline Altruism & $\begin{array}{l}0.0700 \\
(0.581)\end{array}$ & $\begin{array}{l}0.0741 \\
(0.477)\end{array}$ & & \\
\hline Risk-taker & $\begin{array}{l}0.0950 \\
(0.160)\end{array}$ & $\begin{array}{l}0.0631 \\
(0.275)\end{array}$ & & \\
\hline Obedient & $\begin{array}{l}-0.0701 \\
(0.375)\end{array}$ & $\begin{array}{l}-0.0431 \\
(0.515)\end{array}$ & & \\
\hline$N$ & 1173 & 1173 & 919 & 1341 \\
\hline
\end{tabular}

$p$-values in parentheses ${ }^{*} p<0.05,{ }^{* *} p<0.01,{ }^{* * *} p<0.001$

The hypothesis of a positive correlation between boycotts and income failed to be confirmed, with no statistical significance even at 10\% (or 20\%) levels for many models, although most coefficients are (slightly) positive.

Table 3 suggests a consistentrelationship between protest participation and post-materialist values (coefficients that are relatively big and statistical significant even at the $1 \%$ level). This is the only robust correlation with an ideological variable found here. The left-right scale showed significance only for a couple of models of protest participation and one model of boycotts, with 
coefficients in the expected direction (leftists participate more), except for recent participation in protests in $2006 .{ }^{.1}$

The Table 5 show the regression analyses made with the data from NUPPS. That allowed us to include some variables that were not available in WVS: internal and external political efficacy, as well as participation in civic associations. The latter showed statistical significance at the lowest levels for the three dependent variables, confirming all the literature on participation. External political efficacy, in its turn, failed to show significant coefficients. The internal efficacy, on the other hand, was significant and positive (as expected) for petitions and boycotts.

Now, we proceed to some interpretations of these results based on predictions of the models, before some final considerations about those findings.

\section{Predicted probabilities of participation in boycotts - (NUPPS 2006)}

The probability of having participated in boycotts was predicted for the following profiles:

1. Capital city inhabitant, High level of Political Interest, Highest Perception of Internal Political Efficacy, Participates in civic associations activities

PREDICTED PROBABILITY OF HAVING PARTICIPATED IN BOYCOTTS: $23,46 \%$

2. Small town inhabitant, No Political Interest, Lowest Perception of Internal Political Efficacy, DOES NOT participate in civic associations activities

PREDICTED PROBABILITY OF HAVING PARTICIPATED IN BOYCOTTS: $0,005 \%$

II That could be related to the fact that the incumbent government at that time was left-wing since, as we mentioned in TABLE I, the leftists are more active in protests, but when a leftist government is in charge this relationship could be inversed. Nevertheless, it is not safe to make inferences based on this coefficient, since it is not statistically significant. More research on this topic could be useful for that matter. 
Therefore, the predicted probability of participation in boycotts goes from more than $23 \%$ to $0,005 \%$ based on town size, political interest, internal efficacy and participation in civic associations.

Table 4 - Boycott participation - WVS

\begin{tabular}{|c|c|c|c|c|}
\hline & (2006 - Recent) & (2006 - Lifetime) & (I 997- Lifetime) & (1991-Lifetime) \\
\hline \multirow[t]{2}{*}{ Age } & 0.00448 & 0.00935 & 0.0187 & 0.00250 \\
\hline & $(0.655)$ & $(0.252)$ & $(0.115)$ & $(0.762)$ \\
\hline \multirow{2}{*}{$\begin{array}{l}\text { Gender } \\
\text { (female) }\end{array}$} & -0.485 & -0.272 & 0.0378 & -0.0216 \\
\hline & $(0.094)$ & $(0.252)$ & $(0.902)$ & $(0.9 \mid 2)$ \\
\hline \multirow{2}{*}{ Town size } & 0.172 & $0.324^{\star \star *}$ & 0.0119 & $0.114^{*}$ \\
\hline & $(0.119)$ & $(0.001)$ & $(0.838)$ & $(0.047)$ \\
\hline \multirow{2}{*}{ Ocupation } & 0.437 & 0.478 & 0.304 & -0.0217 \\
\hline & $(0.148)$ & $(0.053)$ & $(0.353)$ & $(0.917)$ \\
\hline \multirow{2}{*}{ Income } & 0.0296 & -0.0199 & 0.0749 & 0.0389 \\
\hline & $(0.680)$ & $(0.738)$ & $(0.264)$ & $(0.394)$ \\
\hline \multirow{2}{*}{ Education } & 0.0347 & 0.103 & 0.0949 & $0.174^{* * *}$ \\
\hline & $(0.614)$ & $(0.067)$ & $(0.247)$ & $(0.000)$ \\
\hline \multirow{2}{*}{ Internet } & 0.558 & 0.350 & & \\
\hline & $(0.108)$ & $(0.221)$ & & \\
\hline \multirow{2}{*}{$\begin{array}{l}\text { Political } \\
\text { Interest }\end{array}$} & $0.351^{*}$ & $0.255^{*}$ & $0.519^{* *}$ & $0.508^{* * *}$ \\
\hline & $(0.022)$ & $(0.038)$ & $(0.00 I)$ & $(0.000)$ \\
\hline Political & 0.166 & -0.0338 & -0.0647 & $-0.305^{*}$ \\
\hline Trust & $(0.319)$ & $(0.810)$ & $(0.698)$ & $(0.012)$ \\
\hline
\end{tabular}




\section{(2006 - Recent) (2006 - Lifetime) (1997- Lifetime) (1991- Lifetime)}

$\begin{array}{lcccc}\text { Interpersonal } & 0.292 & 0.120 & 0.692 & -0.646 \\ \text { Trust } & (0.458) & (0.728) & (0.249) & (0.134) \\ & & & & \\ \text { Right-wing } & -0.0292 & -0.0681 & -\mathbf{0 . 1 5 3 ^ { * * }} & -0.0610 \\ & (0.607) & (0.155) & \mathbf{( 0 . 0 0 7 )} & (0.110) \\ \text { Post- } & 0.0853 & 0.128 & & \\ \text { materialist } & (0.500) & (0.227) & (0.228) & (0.005) \\ & & & & \\ \text { Democratic } & 0.0685 & 0.0872 & 0.17 \mathbf{8}^{* *} & \\ \text { Attitude } & (0.386) & (0.184) & (0.369) & \\ & & & & \\ \text { Altruism } & 0.144 & 0.173 & & \end{array}$

$(0.426) \quad(0.254)$

Risk-taker

$\begin{array}{ll}0.157 & \mathbf{0 . 1 6 7}\end{array}$

$(0.084)$

(0.029)

Obedient

$-0.360^{* * *}$

$-0.269^{* *}$

$(0.000)$

$(0.001)$

\begin{tabular}{lllll}
\hline$N$ & 1153 & 1153 & 900 & 1315 \\
\hline
\end{tabular}

$p$-values in parentheses

${ }^{*} p<0.05,{ }^{* *} p<0.01,{ }^{* * *} p<0.001$ 
Table 5 - Non-conventional participation - NUPPS -2006

\begin{tabular}{|c|c|c|c|}
\hline & $\begin{array}{c}\text { (logit) } \\
\text { petition }\end{array}$ & $\begin{array}{c}\text { (logit) } \\
\text { protest }\end{array}$ & $\begin{array}{l}\text { (logit) } \\
\text { Boycott }\end{array}$ \\
\hline Main & 0.00127 & -0.00495 & 0.0135 \\
\hline Income & $(0.977)$ & $(0.949)$ & $(0.906)$ \\
\hline Gender & 0.174 & -0.0967 & -0.337 \\
\hline (female) & $(0.109)$ & $(0.64 I)$ & $(0.293)$ \\
\hline \multirow{2}{*}{ Age } & -0.00108 & 0.00395 & 0.00720 \\
\hline & $(0.785)$ & $(0.636)$ & $(0.550)$ \\
\hline \multirow{2}{*}{ Town size } & $0.197^{* * *}$ & 0.105 & $0.406^{*}$ \\
\hline & $(0.001)$ & $(0.343)$ & $(0.014)$ \\
\hline \multirow{2}{*}{ Ocupation } & 0.236 & 0.163 & 0.407 \\
\hline & $(0.070)$ & $(0.539)$ & $(0.322)$ \\
\hline \multirow{2}{*}{ Education } & $0.145^{* * *}$ & $0.350^{* * *}$ & 0.0885 \\
\hline & $(0.000)$ & $(0.000)$ & $(0.291)$ \\
\hline \multirow{2}{*}{ Political Trust } & $0.174^{*}$ & 0.111 & 0.0791 \\
\hline & $(0.012)$ & $(0.414)$ & $(0.697)$ \\
\hline Interpersonal & 0.0287 & -0.0948 & 0.126 \\
\hline Trust & $(0.676)$ & $(0.475)$ & $(0.512)$ \\
\hline \multirow{2}{*}{ Political Interest } & $0.231^{* * *}$ & $0.485^{* \star \star}$ & $0.378^{*}$ \\
\hline & $(0.000)$ & $(0.000)$ & $(0.027)$ \\
\hline \multirow{2}{*}{ External Efficacy } & 0.00549 & -0.00638 & -0.0271 \\
\hline & $(0.878)$ & $(0.921)$ & $(0.783)$ \\
\hline
\end{tabular}




\begin{tabular}{|c|c|c|c|}
\hline & $\begin{array}{c}\text { (logit) } \\
\text { petition }\end{array}$ & $\begin{array}{c}\text { (logit) } \\
\text { protest }\end{array}$ & $\begin{array}{c}\text { (logit) } \\
\text { Boycott }\end{array}$ \\
\hline Internal Efficacy & $\begin{array}{l}0.137^{* *} \\
(0.003)\end{array}$ & $\begin{array}{l}0.0713 \\
(0.349)\end{array}$ & $\begin{array}{l}0.258^{*} \\
(0.016)\end{array}$ \\
\hline $\begin{array}{l}\text { Democratic } \\
\text { Attitude }\end{array}$ & $\begin{array}{c}0.113^{*} \\
(0.036)\end{array}$ & $\begin{array}{c}0.197 \\
(0.110)\end{array}$ & $\begin{array}{l}0.0888 \\
(0.608)\end{array}$ \\
\hline $\begin{array}{l}\text { Association } \\
\text { Participation }\end{array}$ & $\begin{array}{l}0.378^{* * *} \\
(0.000)\end{array}$ & $\begin{array}{l}1.131^{* * *} \\
(0.000)\end{array}$ & $\begin{array}{l}1.132^{* * *} \\
(0.000)\end{array}$ \\
\hline _cons & $\begin{array}{l}-1.694^{* *} \\
(0.001)\end{array}$ & $\begin{array}{l}-4.410^{* * *} \\
(0.000)\end{array}$ & $\begin{array}{l}-4.065^{* *} \\
(0.009)\end{array}$ \\
\hline$N$ & 1839 & 1840 & 1837 \\
\hline
\end{tabular}

p-values in parentheses

${ }^{*} p<0.05,{ }^{* *} p<0.01,{ }^{* * *} p<0.001$

Table 6 - Predicted probabilities of recent participation in petition signing (WVS 2006)

\begin{tabular}{lcccc}
\hline & \multicolumn{4}{c}{ LevelofPoliticallnterest } \\
\hline EducationalLevel & None & Little & Some & High \\
LessthanPrimarySchool & $\mathbf{0 . 2 4 7 8}$ & 0.2937 & 0.3442 & $\mathbf{0 . 3 9 8 5}$ \\
PrimarySchoolDegree & 0.2922 & 0.3426 & 0.3967 & 0.4535 \\
Incomplete High School & 0.3409 & 0.395 & 0.4518 & 0.5098 \\
High SchoolDegree & 0.3933 & 0.45 & 0.508 & 0.5658 \\
IncompleteUndergraduate & 0.4482 & 0.5062 & 0.564 & 0.6202 \\
Undergraduatedegreeorabove & $\mathbf{0 . 5 0 4 4}$ & 0.5623 & 0.6185 & $\mathbf{0 . 6 7 1 7}$ \\
\hline
\end{tabular}

In TABLE 6, we can see the predicted effect of education and political interest on petition signing. An individual with less than primary school and no political interest has $24.78 \%$ of chance of having ever signed a petition. An individual with a Bachelor's degree or similar has $50 \%$ of chance of having 
done this kind of political action, even if he has no political interest at all. If we look at the last column on the right, an individual with the highest level of political interest and the lowest level of educational background has approximately $40 \%$ of chance of having signed a petition. The profile with the highest levels in both variables would have $67 \%$ of chance of having done this activity.

All these numbers are relatively high, even at the lowest levels of both predictor variables, but we shall bear in mind that this table is for the most frequent type of non-institutionalized participation, the dependent variable stands for having done this kind of activity at least once in a lifetime, and it is for the year of 2006, when online petitions were already becoming widespread along with the Internet.

\section{Conclusion}

Our analysis points to a more relevant role for socioeconomic resources and some political culture variables on unconventional participation than sociopsychological or disaffection models.

Thus, our findings would lean a little bit more to the socioeconomic resources explanations of non-conventional participation over the political disaffection theory. However, as we insisted before, there is no point in opposing these theories. These explanations do not have to be rival. In fact, we have failed to find significant relationships between income and participation in the majority of our models. For boycotting, even education yieldednonsignificant coefficients. On the other hand, political trust was found to be negatively correlated with participation, with statistical significance in a few models. Therefore, this rivalry between disaffection and resources models is not only counterproductive at the theoretical field; it also shows low consistency on our empirical analysis. Dissatisfaction, as well as other factors that increase the willingness to engage in unconventional participation, have their role, as well as resources and other factors that increase the ability and opportunity to participate.

Moreover, the correlation between socioeconomic variables and participation cannot be considered as a direct causal relationship, as Leighley (1995) explains and we commented before. 
The failure to find a positive relationship between education and boycotts deserves some attention. The reasons for that remain unknown. If we had found a positive relationship with income (as we suggested before) we could infer that, after controlling for wealth, education is no longer significant to explain boycotting. But that was not the case. That seem to be a good topic for further research.

The lack of relationship between external political efficacy and participation is also a little difficult to explain. We already know that political participation goes beyond self-centred rational behaviour, but this evidence suggests that participation would go beyond any kind of rationality at all, even if we consider a rational calculus oriented towards collective, selfless goals.

Social relationships as the ones that we try to measure with participation in civic association are, according to Bäck e Christensen (2013), more important than interpersonal trust, as social capital components/proxies, to explain political participation. Our findings confirm that, since interpersonal trust showed no significant coefficients in most of our models.

The consistent relationship between the size of the city and petitionsamong our models raises some curiosity, since we would expect stronger relationships with activities such as demonstrations. This finding suggests that bigger cities provide not only more opportunities for political action (or lower costs for protest participation, as suggested above), but are also more susceptible to this type of action due to other factors, such as cultural variables that are not usually included in the political participation models. That could be an interesting issue for further investigations too.

About these wider waves of protests that swiped out the globe lately, their structural reasons remain unexplained, posing a question for further analysis: why these big demonstration phenomena seem so related to political distrust while individual-level analyses in Brazil and other countries show no correlation between unconventional participation and trust and the political institutions? Are there other variables causing some sort of noise in this relationship? Or could it be that those big waves of protests are different in nature than the daily participation in demonstrations and other non-institutionalized forms of political action? Considering protest participation in Brazil (Table 3), the coefficient for political trust was significant only in 1991, i.e., in most recent years there seem to have no role in explaining why people go to the streets. 
This article aimed to contribute to a more precise understanding of petitions, boycotts and protest participation, as these kinds of activities are different in many ways. It also aimed to contribute to understand nonconventional participation in Brazil. These are not easy tasks. In order to advance in both these goals, more research, with different methodologies and design, would be needed. Qualitative research and surveys focused on participation could provide additional evidences and answer some questions.

\section{Bibliography}

ALESINA, A.; GIULIANO, P. Family ties and political participation. Journal of the European Economic Association, v. 9, n. 5, p. 817-839, 2011.

BARNES, S. H.; KAASE, M.; ALLERBECK, K. R. Political action: Mass participation in five western democracies. Beverly Hills, CA: Sage Publications, 1979.

BOOTH, J. A.; SELIGSON, Mitchell A. Legitimacy and political participation in eight Latin American nations.In: MidwestPolitical Science Meeting, Chicago, IL. 2009.

BORBA, J.; RIBEIRO, E. A. Participaçáo convencional e não convencional na América Latina. Revista Latino-Americana de Opinión Pública, v. 1, p. 53-76, 2010.

BRADY, H. E.; VERBA, S.; SCHLOZMAN, K. L. Beyond SES: A resource model of political participation. American Political Science Review, p. 271-294, 1995.

COHEN, E. H.; VALENCIA, J. Political protest and power distance: Towards a typology of political participation. Bulletin de Méthodologie Sociologique, v. 99, n. 1, p. 54-72, 2008.

CONWAY, M. M. Political participation in the United States. Washington, DC: Congressional Quarterly Press, 1990.

DOWNS, A. An economic theory of political action in a democracy. The Journal of Political Economy, v. 65, n. 2, p. 135-150, Apr., 1957.

DALTON, R. J. Democratic Choices, Democratic Challenges: The Erosion of Political Support in Advanced Industrial Democracies. Oxford University Press, 2004.

. Citizen politics: Public opinion and political parties in advanced industrial democracies. Sage, 2008.

DALTON, R. J.; VAN SICKLE, A.; WELDON, S. The individual-institutional nexus of protest behaviour. British Journal of Political Science, v. 40, n. 01, p. 51-73, 2010. 
DIAMOND, L. J.; MORLINO, L. (Ed.). Assessing the quality of democracy. Baltimore: Johns Hopkins University Press, 2005.

FINKEL, S. E. Reciprocal effects of participation and political efficacy: A panel analysis. American Journal of Political Science, v.29, n.4, p. 891-913, Nov. 1985.

The effects of participation on political efficacy and political support: Evidence from a West German panel. The Journal of Politics, v. 49, n. 02, p. 441-464, 1987.

FOWLER, J. H.; KAM, C. D. Beyond the self: Social identity, altruism, and political participation. Journal of Politics, v. 69, n. 3, p. 813-827, 2007.

GALLEGO, A.; OBERSKI, D. Personality and political participation: The mediation hypothesis. Politicalbehavior, v. 34, n. 3, p. 425-451, 2012.

GEYS, B. Explaining voter turnout: A review of aggregate-level research. Electoral Studies, v. 25 , n. 4 , p. $637-663,2006$.

HALE, T.; HELD, D. (Ed.). The Handbook of Transnational Governance: Institutions and Innovations. Polity, 2011.

KAASE, M. Interpersonal trust, political trust and non-institutionalised political participation in Western Europe. West European Politics, v. 22, n. 3, p. 1-21, 1999.

KLANDERMANS, B. et al. The demand and supply of participation: Social-psychological correlates of participation in social movements. In: SNOW,D.A.; SOULE, S.A.; KRIESI, H. (eds), The Black-well Companion to Social Movements. Blackwell: Oxford, 2004, p. 360-379.

LEIGHLEY, J. E. Attitudes, opportunities and incentives: A field essay on political participation. Political Research Quarterly, v. 48, n. 1, p. 181-209, 1995.

MARIEN, S.; HOOGHE M.; QUINTELIER, E. Inequalities in Non-institutionalised Forms of Political Participation: A Multi-level Analysis of 25 countries. Political Studies, v. 58, n. 1, p. 187-213, February 2010.

MCALLISTER, I. Political behaviour: citizens, parties and elites in Australia. Melbourne: Longman Cheshire, 1992.

MOISES, J. Á. A desconfiança nas instituiçóes democráticas. Opin. Publica, Campinas , v. 11, n. 1, Mar. 2005

Os significados da democracia segundo os brasileiros. Opiniáo Pública, v. 16, n. 2, p. 269-309, 2010. 
MONDAK, J. J. et al. Personality and civic engagement: An integrative framework for the study of trait effects on political behavior. American Political Science Review, v. 104, n. 01, p. 85-110, 2010.

The participatory personality: evidence from Latin America. British Journal of Political Science, v. 41, n. 01, p. 211-221, 2011.

MULLER, E. N.; OPP, K. Rational choice and rebellious collective action. The American Political Science Review, n. 80, p. 471-488, 1986.

NORRIS, P. (Ed.). Critical Citizens: Global Support for Democratic Government: Global Support for Democratic Government. Oxford University Press, 1999.

NORRIS, P. Democratic phoenix: Reinventing political activism. Cambridge University Press, 2002.

NORRIS, P.; WALGRAVE, S.; VAN AELST, P. Who demonstrates? Antistate rebels, conventional participants, or everyone? Comparative politics, v. 37, n.2, p. 189-205, 2005.

OLSON, M. The logic of collective action. Public goods and the theory of groups. Harvard University Press, 1956.

OPP, K.; BRANDSTÄTTER, H. Political protest and personality traits: a neglected link. Mobilization: An International Quarterly, v. 15, n. 3, p. 323-346, 2010.

RIKER, W. H.; ORDESHOOK, P. C. A Theory of the Calculus of Voting. American Political Science Review, v. 62, n. 01, p. 25-42, 1968.

SCHUSSMAN, A.; SOULE, S. A. Process and protest: Accounting for individual protest participation. Social Forces, v. 84, n. 2, p. 1083-1108, 2005.

SCHWARTZ, S. H. Universals in the content and structure of values: Theoretical advances and empirical tests in 20 countries. Advances in experimental social psychology, v. 25, n. 1, p. 1-65, 1992.

SCHWARTZ, T. Your vote counts on account of the way it is counted: An institutional solution to the paradox of not voting. Public Choice, v. 54, n. 2, p. 101-121, 1987.

SINGER, A. Brasil, junho de 2013, classes e ideologias cruzadas. Novos Estudos-CEBRAP, n. 97, p. 23-40, 2013.

STOLlE, D.; HOOGHE, M.; MICHELETTI, M. Politics in the supermarket: Political consumerism as a form of political participation. International Political Science Review, v. 26, n. 3, p. 245-269, 2005. 
THOMAS, C. S. (Ed.). Political parties and interest groups: shaping democratic governance. Lynne Rienner Publishers, 2001.

ULBIG, S. G.; FUNK, C. L. Conflict avoidance and political participation. Political Behavior, v. 21, n. 3, p. $265-282,1999$.

WEINSCHENK, A. 'Cause You've Got Personality Political Participation and the Tendency to Join Civic Groups. SAGE Open, v. 3, n. 4, p. 1-12, Oct. 2013.

WHITELEY, P.; SEYD, P. Rationality and party activism: Encompassing tests of alternative models of political participation. European Journal of Political Research, v. 29, n. 2, p. 215-234, 1996.

\section{Appendix - codebook}

\section{Dependent Variables}

- Political action done recently (WVS 2006) - dummy variables where yes $=1$ and no $=0$, for the question:

"Have you or have you not done any of these activities in the last five years?"

- Signing a petition (peticao_recente)

- Joining in boycotts (boicote_recente)

- Attending peaceful demonstrations (protesto_recente)

- Political action ever done (WVS 1991, 1997 e 2006), dummy variables where yes $=1$ and no= 0 , for the question:

"I'm going to read out some forms of political action that people can take, and I'd like you to tell me, for each one, whether you have done any of these things, whether you might do it or would never under any circumstances do it:

- Signing a petition

- Joining in boycotts

- Attending peaceful demonstrations"

In the NUPPS databank, the question is fairly the same, if we translate from Portuguese to English. 


\section{Independent Variables}

Personal income

\section{WORLD VALUES SURVEY}

For every year, this variable is coded in 10 categories. Nonetheless, the 1991 wave measured it in a very unusual fashion, asking every individual where do they think they stand in relation to the national income distribution (the interviewee should assign 5 if he believes his income is right in the country average). In 1997 and 2006, a more common, objective measure was used, from no income/less than minimum wage on.

\section{NUPPS}

In this research, income was measured in two different ways. For half of the sample, it was used a categorical variable (similarly to 1997 and 2006 waves of WVS, right above). For the other half, an open question was asked and the person could answer any value. We unified the whole sample into a single categorical variable.

\section{Education}

\section{World Values Survey}

This variable was also measured in different manners across the different waves of WVS:

1991 - 4 categories

1997 - 8 categories - from incomplete elementary school to complete university degree or more.

2006 - 6 categories - there was one category for "no formal education at all" with only 20 interviewees, according to the International Codebook of the 2005-2007 wave (in the Brazilian 2005's questionnaire this category is also shown). However, in the databank this level appears already aggregated with the next one ("incomplete elementar school").

NUPPS - Categorical variable in 8 categories, very similar to WVS 2006. 
Gender - dummyvariable for both databank $(1=$ female, $0=$ male $)$

Age - continuous variable standing for years old in the moment of the interview.

Ocupation - dummy variable ( $1=$ working in the moment of the interview; $0=$ not working)

Townsize - population size of the city where each interview was taken (categorical variable)

Political Interest- ordinal variable (4 categories)

Political Trust - ordinal variable (4 categories), for the level of trust in parliament.

Interpersonal trust - answer to the question: "Generally speaking, would you say that most people can be trusted or that you need to be very careful in dealing with people?"

$0=$ Need to be very careful.

$1=$ Most people can be trusted.

Association participation - dummy variable

$1=$ participates in some kind of civic association

$0=$ does not take part.

Democratic Attitude -

In WVS databanks, we used the following question (coded into four categories):

"I'm going to describe various types of political systems and ask what you think about each as a way of governing this country. For each one, would you say it is a very good, fairly good, fairly bad or very bad way of governing this country?

- Having a democratic political system."

The variable was recoded in the following way:

$1=$ fairly bad 
$2=\mathrm{bad}$

$3=\operatorname{good}$

$4=$ fairly good

In NUPPS databank, we used the following question (coded into 5 categories):

"Now I will read a statement and I would like you to tell me whether you agree or disagree with it:

Democracy might have its problems, but it is the best government system."

The variable was recoded in the following way:

$1=$ strongly disagree

$2=$ disagree

$3=$ do not agree or disagree

$4=$ agree

$5=$ strongly agree

Ideology (only WVS):

In political matters, people talk of "the left" and "the right." How would you place your views on this scale, generally speaking? (Code one number):

$1=\mathrm{left}$

$10=$ right

Internal efficacy - based on the question: "Now I will read some statements about politics and I would like you to tell whether you agree or disagree with each of them:

- politics and government seem so much complicated that people like myself cannot understand what is happening."

The answers were coded as follows:

$1=$ strongly disagree 
$2=$ disagree

$3=$ do not agree or disagree

$4=$ agree

$5=$ strongly agree

External efficacy - The head of the question and coding of the answers were similar to internal efficacy, but this variable is based on the following item of the question: "people like myself do not have influence on what the government does."

Internet - dummy variable $(1=$ has Internet connection $0=$ does not have Internet connection)

The questions related to personality and values on WVS feature 6 categories and were based on the following question:

"Now I will briefly describe some people. Using this card, would you please indicate for each description whether that person is very much like you, like you, somewhat like you, not like you, or not at all like you?"

Obedient = It is important to this person to always behave properly; to avoid doing anything people would say is wrong.

Altruism = It is important to this person to help the people nearby; to care for their well-being.

Risk-taker $=$ Adventure and taking risks are important to this person; to have an exciting life.

\section{Determinantes da participação não-convencional no Brasil}

\section{Resumo}

O presente artigo tem como objetivo uma análise da participação em protestos, petições e boicotes no Brasil. Utilizando dados do World Values Survey e de uma pesquisa de opinião conduzida 
pelo NUPPS-USP (Núcleo de Pesquisas em Políticas Públicas da Universidade de são Paulo), foram realizadas regressões logísticas para avaliar o impacto de variáveis como eficácia, confiança e interesse por política, além de recursos econômicos como educação, nessas três formas de participação. Confirmando proposições teóricas e evidências empíricas na literatura, os resultados aqui apresentados sugerem que educação e interesse por política apresentaram correlação positiva e estatisticamente significante nos três tipos de ação política, na maioria dos modelos aqui testados. O tamanho da cidade apresentou resultados curiosos: em alguns modelos, ele apresenta uma correlação positiva com a participação, em especial para petições. Isso sugere que cidades maiores proporcionam não apenas mais oportunidades físicas de ação política (o que impactaria sobre tudo a participação em protestos), mas são também mais suscetíveis a esse tipo de ação, devido a outros fatores, como variáveis da cultura política não captadas nos modelos de participação política em geral.

Palavras-chave: Participação política. Manifestações. Petições. Boicotes. 